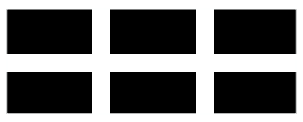

ThE William DAVIDSON INSTITUTE AT THE UNIVERSITY OF MICHIGAN BUSINESS SCHOOL

Does the World Bank have any impact on human development of the poorest countries? Some preliminary evidence from Africa

\author{
By: Sumon Kumar Bhaumik
}

William Davidson Institute Working Paper Number 784

August 2005 


\title{
Does the World Bank have any impact on human development of the poorest countries? Some preliminary evidence from Africa*
}

\author{
Sumon Kumar Bhaumik ${ }^{* *}$ \\ Queen's University Belfast, \\ CNEM, London Business School, and \\ William Davidson Institute, Ann Arbor
}

June 25, 2005

\begin{abstract}
:
In an attempt to better understand the impact of the World Bank on human development in poor countries, we use cross-country data on African countries, for the 1990-2002 period, to examine this relationship. The coefficient estimates of our parsimonious fixed-effects models indicate that while loans and grants of the Bank have had a positive impact on some relatively short-term indicators of health and education in an average African country, there is little evidence to suggest that such loans and grants have helped these countries to consolidate on the short-term gains.
\end{abstract}

Keywords: $\quad$ Development, Health, Education, World Bank, Africa

JEL classification: O15, O19, O55, P45

\footnotetext{
* The author would like to thank Stephen Gelb and Stephanie Levy for their valuable comments, and Anupa Bhaumik for help with procurement of the data. He would also like to thank the Ali Kutan, Ayse Evrensel and an anonymous referee for their patience and helpful comments. The usual disclaimers apply. In particular, this paper does not necessarily reflect the views of the World Bank.

** School of Management and Economics, Queen's University Belfast, 25 University Square, Belfast BT7 1NN, United Kingdom. Phone: +44 28 9097-3273, Fax: +44 28 9097-5156. Email: sbhaumik@alumni.usc.edu.
} 


\section{Introduction}

The politics of economic development has witnessed a remarkable transformation during the past few years. For three decades, starting with the collapse of the Bretton Woods agreement and oil price shock in the 1970s, the focus of economists and policymakers in developed economies remained firmly on the rise and demise of stagflation as a phenomenon, the rising productivity and economic growth in (largely) East Asia, the emergence of a common currency in Europe, the rise of China as a global power, and the transition of (most of) the former Soviet block countries from planned to market economies. Geopolitics and, ironically, globalization, which has made countries co-dependent on each other in more than one ways, have once again brought to the fore issues like poverty elimination, and policy challenges like forgiving the sovereign debt of the poorest countries as the way to attain this goal. Indeed, poverty, largely in the African context, and sovereign debt forgiveness lies at the heart of the 2005 meeting of the G-8 countries.

While the discussion about world poverty is welcome - even though it remains to be seen whether the proposals making their rounds in the corridors of the G-8 governments, and international organizations like the United Nations get translated into concrete action - this discussion has also brought into focus the role played by the World Bank over the decades. The Bank has had the mandate to promote economic development and reduce poverty levels across the world since its inception, and yet, as of 2002, 28 percent of the global population lived in poverty. ${ }^{1}$ More importantly, while there has been a 7 percentage point decline in the proportion of the world population living in poverty just during the 19902001 period, much of this decline has been on account of rapid economic growth in East Asia (including China) and South Asia. The impact of aid, which includes a substantial financial commitment by the World Bank, on growth and development has been particularly uninspiring in Africa. Indeed, while aid has averaged 6 percent of GDP across the region, average per capita income in Africa was 15 percent lower in the mid 1990s than the corresponding figures in the late 1970s (Lancaster, 1999). This has provoked the detractors of the World Bank to conclude that the Bank has been ineffective in delivering on its mandate, and that therefore it has to be significantly restructured. In particular, it has been argued that rather than provide conditional aid to all less developed countries, the Bank should evolve into a Knowledge Bank and lend only to countries that have good policies and good institutions (see, e.g., Gilbert, Powell and Vines, 1999).

In evaluating the Bank's performance in the context of facilitating development in the poor countries, a more relevant question perhaps is whether the Bank's impact on the developing countries is in the form of short-term improvement in social indicators, especially for the vulnerable sections of the

\footnotetext{
${ }^{1}$ The poverty line is defined as USD 1.08 in 1993 dollars, adjusted for differences in purchasing powers across countries.
} 
population, or whether it helps build sustainable processes that would deliver increasing proportion of the population out of poverty over time. It has been argued that "[w]hile poverty alleviation is its major mandate, the World Bank is not designed to run ........ relief-based projects that touch the hard-core poor directly” (Wallich, 1995, pp. 90). However, relief-based operations, while important in the context of widespread human suffering in many parts of the world, do not necessarily contribute to poverty alleviation in the long run. In view of the reasonable assumption that poverty is largely a consequence of entitlement failure (Sen, 1981), this begs a discussion about the impact of the Bank on the ability of the poorer sections of developing country populations to transform labor power into earnings, and, therefore, consumption. Since entitlement failure is usually brought about by low productivity among laborers who do not have access to non-wage income (Dasgupta and Ray, 1986; Dasgupta, 1993), ${ }^{2}$ any discussion about the role of the World Bank in facilitating long-term development has to evaluate the impact of the Bank’s lending activities on health and education.

To recapitulate, Sen (1981) argued that poverty, as manifested by low levels of consumption, is largely a consequence of the inability of individuals to translate their labor endowment into income stream by way of gainful employment. This process of (labor) market failure is known as entitlement failure. Dasgupta and Ray (1986) and Dasgupta (1993) examine the nature of this entitlement failure. They assume that an individual is productive only after her consumption reaches some minimum threshold. If an individual who does not consume this minimum amount participates in the labor market, her real wage (which is positive) would necessarily exceed her productivity (which is zero). Hence, she will not be hired by any employer, and she will experience entitlement failure. It is evident that elimination of poverty requires short-term intervention that can increase the non-wage income of the poor individuals such that there is an increase in both their consumption, and hence productivity, as well as their ability to accept lower real wages, thereby preventing a market failure. ${ }^{3}$ However, a long run (or permanent) resolution of the problem would require a permanent increase in the productivity of potential labor force participants, and such an increase in productivity can only be brought about by an improvement in the health and education of the relevant individuals.

In this paper, we address this issue. Specifically, using cross-country data from Africa, we estimate the impact of the World Bank's assistance on different measures of health and education in the African countries. The evidence about the impact of aid, in general, on economic development is

\footnotetext{
${ }^{2}$ Entitlement failure can also be brought about by factors like food-feed competition in an environment of unequal income and wealth distribution (Baland and Ray, 1991). However, the discussion of such issues lies outside the scope of this paper.

${ }^{3}$ It is easy to see why policies concerning elimination of poverty have historically focussed on provision of subsidised food to poorer sections of the society, creation of public works project to generate employment, and the provision of subsidies to (especially, small and medium) firms that generate private sector employment in developing countries.
} 
controversial. Burnside and Dollar (2000) demonstrated that aid does have a positive impact on economic development, but only in good policy environments. However, using the same data definitions and methods, Easterly (2003) and Easterly, Levine and Roodman (2004) show that the nature of this impact is significantly dependent on the choice of the time period. Finally, using long time series data for 45

countries, Burhop (2005) found no causal relationship between foreign assistance and economic development. Given the conflicting evidence documented in the literature, and given the existing anecdotal evidence, our prior is that the Bank's assistance can, at best, have a transient impact on human welfare in these countries. As we shall see later in the paper, this prior is borne out by the data.

The rest of the paper is organized as follows: In Section 2, we describe the data. In Section 3, we report the empirical strategy for the analysis and the results, and discuss the latter. Section 4 concludes.

\section{Data}

The data were obtained from the DDP and World Development Indicator archives of the World Bank, and is fraught with the problem of missing values. While there is significant time series data for macroeconomic variables like GDP per capita (both in PPP and USD terms) and GDP growth, the data on development, budgetary allocation for health and education etc are absent for most of the years for many of the countries in our sample. This makes it difficult for us to measure changes in the indicators of health and development for the same time periods, across all (or most of) the countries. A closer examination of the data led us to choose the 1995-2002 period for health and the 1990-2000 period for education.

The summary statistics are reported in Table 1 . The table reflects the extent of the missing value problem with the data set. While estimates for indicators of health and macroeconomic variables like per capita GDP are available for these countries for the relevant time periods, estimates for indicators of education are relatively more difficult to obtain. We were, therefore, faced with the choice of reporting the means and standard deviations for all these variables using a sample of only those countries for which all the relevant data are available, and reporting the aforementioned means and standard deviations for all countries for which data are available for a specific variable. We chose the latter option, in order to be able to provide as complete a picture of the trends in human development in Africa as allowed by the available data, and hence the different values for $N$ (i.e., number of observations) for the variables for which means and standard deviations are reported in Table 1.

INSERT Table 1 about here.

The descriptive statistics suggest that an average African country has witnessed an improvement in both health and education indicators during the 1990s; mortality prior to the first birthday declined by 
about 5 per 1000 during 1995-2002, and mortality prior to the fifth birthday declined by 7.5 per 1000 . During the same time period, there was no significant change in the proportion of public expenditure on health; it rose from 2.26 percent of GDP to 2.45 percent of GDP. In keeping with our expectations, the mean values do not adequately reflect the sharp inter-country variations. Egypt, for example, witnessed a drop of 23 in its mortality rate prior to the first birthday, while in Botswana there was actually an increase of 30 in the same measure of health during the same time period. Egypt also witnessed a sharp drop in the mortality rate prior to the fifth birthday, a reduction of 32, as did countries like Eritrea and Nigeria (reduction of 37 each). At the other extreme, mortality before the fifth birthday rose by 33 in Zimbabwe and by 44 in Botswana. Similarly, while Botswana witnessed an increase in its public health expenditure to GDP ratio by over 2 percentage points, there was a decline in this ratio for countries like Malawi (0.39), Zambia (-0.3) and Namibia (-0.20).

We adopt three indicators of the state of education in a country, namely, the proportion of a student cohort that persists till the fifth grade, the proportion of a student cohort that successfully completes primary education, and literacy among youths in the 15-24 age-group. The descriptive statistics indicate that there was an improvement in Africa for all these three measures during the 1990-2000 period, with the most noticeable change occurring in the measure for youth literacy. As in the case of health, there are significant inter-country variations for these measures. Countries like Benin, Guinea and Togo witnessed a sharp increase in the proportion of incoming students who complete reach the fifth grade, by 28.97, 28.11 and 23.46 percentage points, respectively, while countries like Gambia (-18.05), Ghana (-14.18) and Senegal (-12.19) experienced reductions in their retention rates. Benin (20.11), along with countries like Malawi (22.60), Tunisia (15.89) and Algeria (13.18), also saw an improvement in the proportion of students successfully completing primary education, while countries like Mauritius (30.64), Central African Republic (-27.81) and Kenya (-20.69) were laggards in this category. Importantly, all the countries in the sample for which data are available, with the exception of Mali, witnessed an increase in the youth literacy rate, with the best performance witnessed in countries like Chad (18.55), Nigeria (13.34) and Sudan (12.20). Data on government or public expenditure on education in the African were not available.

The backdrop of these changes in indicators of health and education remained slow pace of economic growth in the average African country. During the 1990-98 period, the GDP per capita across African countries increased by an average of USD 172.57, when measured in terms of purchasing power parity. The biggest positive changes were observed in Seychelles (3532.63), Mauritius (2267.62) and Tunisia (1103.84), while the loss of PPP income per head was most pronounced in South Africa (632.46), Sierra Leone (-466.47) and Angola (-450.66). The correlation between the 1990-98 change in per capita PPP GDP and the 1990 (i.e., initial) value of PPP GDP was 0.60, indicating that, in Africa, during 
the 1990s, relatively well-off countries were likely to witness greater development when measured in terms of per capita PPP GDP. Clearly, there is prima facie evidence to suggest that, in Africa, there are pockets of virtuous (and, correspondingly, vicious) cycles of economic growth (decline).

Finally, the average exposure of the IBRD and IRD to an average African country increased significantly during the 1990-2000 period, by about USD 231 million. The volume of World Bank aid increased in 35 of the 44 countries for which data are available. Uganda (USD 1.15 billion), Zambia (1.04 billion) and Ethiopia (928 million) received the largest increase in aid, while the decline in aid was the sharpest in Tunisia (158 million), Botswana (144 million) and Mauritius (95.7 million).

Ideally, any empirical exercise involving the exploration of the impact of the World Bank's activities in African countries on human development in these countries should involve a panel data, and associated modeling techniques like the generalized method of moments which can correct for endogeneity of key explanatory variables. However, as explained in the previous section, our data is hostage to missing values, and that makes it impossible to use any panel data model for estimation purposes. Further, the data set does not include any variable that captures the nature of the political economy of these countries, as aspect of all developing countries that plays a key role in determining human development thereof. In the course of the empirical investigation, we, therefore, base our estimations on a fixed effect model, and treat all country specific political and policy issues as fixed effects. This strategy is not inconsistent with the history of a continent where countries have had one political paradigm - de facto dictatorship (e.g., Egypt, Zimbabwe), single party dominance (e.g., South Africa), sustained war (e.g., Sierra Leone, Angola) - in most of the countries, throughout much or all of the 1990s. Further, while an examination of the impact of institutions on human development is an important endeavor by its own right, the focus of this paper is the impact of the World Bank's exposure to African countries on human development in those countries, and our empirical strategy is adequate for our purposes.

\section{Empirical strategy and Results}

We start with the following basic model:

$\operatorname{HUMANDEV}_{\mathrm{i}}=\beta_{0 \mathrm{i}}+\beta_{1 \mathrm{i}}$ WORLDBANK $+\varepsilon_{\mathrm{I}}$

Where, in any given year, human development (HUMANDEV) in country $i$ is measured using variables like mortality rate and educational attainment, the World Bank's activities (WORLDBANK) is measured using the amount of financial resources transferred to the country by IBRD and IRD, and $\varepsilon$ is the iid error term. It can evident that specification [1a] can be used to generate the difference-in-difference specification that controls for all country-specific fixed effects, political as well as non-political. The difference-in-difference specification is given by 
$\triangle$ HUMANDEV $_{\mathrm{i}}=\beta_{0 \mathrm{i}}+\beta_{1 \mathrm{i}} \Delta$ WORLDBANK $+\varepsilon_{\mathrm{I}}$

In order to ensure that the regression model is not misspecified, we expand the specification to control for factors like changes in the standard of living in the countries, as measured by their per capita GDP (PCGDP). Since a country's per capita GDP is the culmination of all factors that affect economic growth, including factors like governance and rule of law, in the absence of detailed data on key aspects of the economy and institutions of the African countries, controlling for per capita GDP would allow us to control for a variety of factors that affect human development in a country. We measure GDP in terms of purchasing power parity US dollars. ${ }^{4}$

We also control for other key factors that are likely to affect health and education in a country (OTHER). In the context of health, we separately control for the ratio of public expenditure on health to the GDP, and the ratio of public health expenditure to private health expenditure. Both measures are aimed to capture the quality and quantity of medical services available to the population of these countries. In the context of education, we control for the initial and mid-period adult literacy levels, which is consistent with the stylized view that the level of educational attainment has a high degree of persistence across generations. Unlike in the case of health, we do not use the ratio of public expenditure on education to GDP because the relevant data are unavailable. The revised specification, therefore, is as follows:

$\Delta$ HUMANDEV $_{\mathrm{i}}=\beta_{0 \mathrm{i}}+\beta_{1 \mathrm{i}} \Delta$ WORLDBANK $+\beta_{2 \mathrm{i}} \Delta$ PCGDP $+\beta_{3 \mathrm{i}} \Delta$ OTHER $+\varepsilon_{\mathrm{I}}$

Finally, we take into account the possibility that changes in GDP in a country may be endogenous to factors that influence health and education in that country. For example, a significant expenditure on public health in an African country may manifest both a benevolent (perhaps democratically elected) government with policies that foster growth, as well as the (negative) impact of infectious diseases like HIV, which can affect public expenditure significantly, on the country's growth. We control for this endogeneity by using initial values of the GDP per capita (IPCGDP), implicitly making the reasonable assumption that economic growth and prosperity is significantly determined by the initial state of the economy. The specification for these set of regressions is

$\Delta$ HUMANDEV $_{\mathrm{i}}=\beta_{0 \mathrm{i}}+\beta_{1 \mathrm{i}} \Delta$ WORLDBANK $+\beta_{2 \mathrm{i}}$ IPCGDP $+\beta_{3 \mathrm{i}} \Delta$ OTHER $+\varepsilon_{\mathrm{I}}$

We estimate regression models [1c] and [1d] using ordinary least squares (OLS); the standard errors are robust and corrected for possible heteroskedasticity. The regression results are reported in Tables 2 and 3. In Table 2, we report the impact of a change in IBRD and IRD loans and grants on measures of health status of an average African country, during the 1995-2002 period. Similarly, in Table 3 , we report the impact of a change in such loans and grants on measures of its educational attainment.

\footnotetext{
${ }^{4}$ We also experimented using measures of per capita GDP based on the 1995 exchange rate based US dollars. Our results, discussed later in the paper, remained robust to this alternative measurement of GDP per capita.
} 
We report two specifications in Table 2: Model 1 in the table corresponds to specification [1c] where all explanatory variables are measured in first-difference terms. Model 2, on the other hand, corresponds to specification [1d] where the public expenditure on health continues to be measured in first-difference terms but the change in per capita PPP GDP is replaced by the initial (i.e., 1995) value of the same variable. Similarly, in Table 4, we report four specifications: In Models 1 and 2, PPP GDP is expressed in first-difference terms, while in Models 3 and 4, we use the initial (i.e., 1990) value of this variable. In addition, in Models 1 and 3, we use the initial value of the adult literacy rate, while in Models 2 and 4 we use the mid period (i.e., 1995) value of this literacy variable.

INSERT Tables 2 and 3 about here.

The coefficient estimates reported in Table 2 suggest that the World Bank does play a role in infant mortality in Africa, when infant mortality refers to mortality rate (per 1000) prior to the first birthday. Specifically, any increase in the volume of IBRD and IDA loans and grants reduces infant mortality rates in an average African country. The coefficient estimates for the $\triangle W O R L D B A N K$ variable is significant at (mostly) the 5 percent level or the 10 percent level for all the regression models, i.e., this result is robust to the choice of the specification and the measurement of the control variables. The adjusted R-squares associated with the regression models too are reasonable for the sample size, and comparable with empirical studies involving cross-section data. These indicate that our specifications fit the data reasonably well despite the missing data problem that restricts the sample size to about 36 .

By the same token, however, our specification is much less capable of explaining variations in the child mortality rate in Africa, when child mortality is defined as the mortality rate (per 1000) of children prior to their fifth birthday. Further, while our coefficient estimates suggest that the World Bank's loans and grants may have reduced child mortality in an average African country, the significance level of these coefficients is much weaker than our estimates for infant mortality, 15 percent for former as opposed to 5 and 10 percent for the latter. This provides prima facie evidence that while the World Bank has had a significant positive impact on aspects of health (e.g., infant mortality) where short-term aid or help is critical, the Bank has not been as successful at promoting long-term institutions and infrastructure that sustains and builds on these short-term gains over time.

The coefficient estimates reported in Table 3 highlight a similar pattern in the context of education. While loans and grants from IBRD and IRD seem to have had a positive effect on the completion rate of primary education in an average African country, during the 1990-2000 period, there is no significant impact on either the ability of the education system to retain students till the fifth grade, and ability of the Bank to influence the youth literacy rate is weak at best. The adjusted R-squares associated 
with the models too indicate that while our specification explains well the cross-country variation in the completion rate of primary education, it is not as good at explaining cross-country variations in the other two measures of educational attainment. However, we draw encouragement from the fact that, to the extent that the impact of the Bank's loans and grants on the youth literacy rate is significant, this impact is positive.

\section{Concluding Remarks}

In the backdrop of a controversy about the extent to which the World Bank has played a significant role in reducing world poverty, we use cross-country data from African countries to empirically estimate the impact of the Bank's loans and grants on two key human attributes that determine the probability of entitlement failure, and hence poverty, in the long run. These two attributes are health and education. Our data, spanning the 1990-2002 period, suffers from missing value problems, which is not unusual, given the unrest in a number of countries in the African continent. On the one hand, this reduces the number of usable observations significantly, to between 30 and 35 in most cases. On the other hand, this problem also eliminates from the usable sample countries like Liberia and Democratic Republic of Congo that are outliers even in the African context, and might, therefore, have biased the regression estimates.

The regression estimates themselves are remarkably robust across specifications, and the relationships the significant estimates capture between the World Bank's loans and grants and measures of health and educational status in an average African country are consistent with our priors. The estimates suggest that while the Bank was possibly fairly successful in mitigating health and education related problems in the short run, it possibly did not have much impact on the sustainability of these benign effects in the long run. Given anecdotal evidence about the state of governance in an average African country, this is not altogether unexpected. Further, this result is consistent with existing evidence that performance of World Bank funded projects increase with supervision (Kilby, 2000), the ability of the Bank to supervise being greater for projects that have near term impacts like reducing mortality at birth. More importantly, it brings to light the importance of governance in enabling human development using multilateral aid as a vehicle. The policy implication, which is broadly in line with the G-8 consensus, is that multilateral agencies like the World Bank and the implicit donor countries would have to simultaneously provide aid, which has a significant near term impact on human development, and, at the same time, use appropriate incentives and suasion to improve the state of governance in the recipient countries, to be able to successfully break the vicious circles of poverty in these countries.

The paucity of high quality data makes empirical analysis of African countries a challenging proposition. Indeed, our own paper merely highlights some plausible relationships between the World 
Bank's loans and grants to an average African country and the extent of its human development, as measured by some indicators of health and education. However, we feel that we have been able to provide some solid prima facie evidence about the impact of the World Bank on human development in Africa, and have also been successful in raising some important questions about the time horizon of the impact of such loans and grants. As such, our results should stimulate greater research on the causal relationship that we investigate in this paper, if necessary, using case studies, in case high quality data for more rigorous empirical research remains unavailable. 


\section{References}

Baland, J.M. and D. Ray, 1991, Does asset quality affect unemployment? A study of the demand composition problem, Journal of Development Economics 35, 69-92.

Burhop, C., 2005, Foreign assistance and economic development: A re-evaluation, Economic Letters 86, 57-61.

Burnside, C. and D. Dollar, 2000, Aid, policies, and growth, American Economic Review 90, 847-868.

Dasgupta, P. and D. Ray, 1986, Inequality as a determinant of malnutrition and unemployment: Theory, Economic Theory 96, 1011-34.

Dasgupta, P., 1993, Inquiry into well-being and destitution (Clarendon Press, Oxford).

Easterly, W., 2003, Can foreign aid buy growth? Journal of Economic Perspectives 17, 23-48.

Easterly, W., R. Levine, D. Roodman, 2003, New data, new doubts: A comment on Burnside and Dollar's “Aid, policies, and growth” (2000), American Economic Review 94, 774-780.

Gilbert, C., A. Powell and D. Vines, 1999, Positioning the World Bank, The Economic Journal 109, 598633.

Kilby, C., 2000, Supervision and performance: The case of World Bank projects, Journal of Development Economics 62, 233-259.

Lancaster, C., 1999, Aid effectiveness in Africa: The unfinished agenda, Journal of African Economies 8, 487-503.

Sen, A.K., 1981, Poverty and famines: An essay into entitlement and deprivation (Oxford University Press, Oxford).

Wallich, C.I., 1995, What's right and wrong with World Bank involvement in Eastern Europe? Journal of Comparative Economics 20, 57-94. 
Table 1

Descriptive Statistics

\begin{tabular}{|c|c|c|c|}
\hline Health (1995-2002) & Initial & Final & Change \\
\hline $\begin{array}{l}\text { Mortality rate prior to } 1^{\text {st }} \text { birthday (per } 1000 \text { ) } \\
{[\mathrm{N}=52]}\end{array}$ & $\begin{array}{r}94.84 \\
(39.59) \\
\end{array}$ & $\begin{array}{r}89.82 \\
(38.27) \\
\end{array}$ & $\begin{array}{r}-5.01 \\
(10.83)\end{array}$ \\
\hline $\begin{array}{l}\text { Mortality rate prior to } 5^{\text {th }} \text { birthday (per } 1000 \text { ) } \\
{[\mathrm{N}=52]}\end{array}$ & $\begin{array}{r}149.67 \\
(70.80) \\
\end{array}$ & $\begin{array}{r}142.32 \\
(69.16) \\
\end{array}$ & $\begin{array}{r}-7.34 \\
(17.43)\end{array}$ \\
\hline $\begin{array}{l}\text { Public expenditure on health as \% of GDP } \\
\text { (percentage point) }[\mathrm{N}=53]\end{array}$ & $\begin{array}{r}2.26 \\
(1.15) \\
\end{array}$ & $\begin{array}{r}2.45 \\
(1.07) \\
\end{array}$ & $\begin{array}{r}0.19 \\
(0.70) \\
\end{array}$ \\
\hline $\begin{array}{l}\text { Ratio of public to private expenditure on health (\% of } \\
\text { GDP) }[N=52]\end{array}$ & $\begin{array}{r}1.39 \\
(0.95)\end{array}$ & $\begin{array}{r}1.49 \\
(0.98)\end{array}$ & $\begin{array}{r}0.09 \\
(0.55)\end{array}$ \\
\hline Education (1990-2000) & Initial & Final & Change \\
\hline $\begin{array}{l}\text { Increase in persistence to grade } 5 \text { (percentage point) } \\
{[\mathrm{N}=25]}\end{array}$ & $\begin{array}{r}71.35 \\
(19.48)\end{array}$ & $\begin{array}{r}74.29 \\
(17.45) \\
\end{array}$ & $\begin{array}{r}2.93 \\
(13.18)\end{array}$ \\
\hline $\begin{array}{l}\text { Increase in primary completion rate (percentage } \\
\text { point) } \\
{[\mathrm{N}=32]}\end{array}$ & $\begin{array}{r}52.10 \\
(28.18)\end{array}$ & $\begin{array}{r}53.75 \\
(26.05)\end{array}$ & $\begin{array}{r}1.64 \\
(14.91)\end{array}$ \\
\hline $\begin{array}{l}\text { Increase in youth literacy (percentage point) } \\
{[\mathrm{N}=37]}\end{array}$ & $\begin{array}{r}67.68 \\
(20.21) \\
\end{array}$ & $\begin{array}{r}75.52 \\
(17.69) \\
\end{array}$ & $\begin{array}{r}7.84 \\
(4.24) \\
\end{array}$ \\
\hline Macroeconomic Environment (1990-98) & Initial & Final & Change \\
\hline $\begin{array}{l}\text { Increase in level of GDP per capita (PPP USD) } \\
{[\mathrm{N}=46]}\end{array}$ & $\begin{array}{r}2261.22 \\
(2349.59) \\
\end{array}$ & $\begin{array}{r}2433.79 \\
(2827.43) \\
\end{array}$ & $\begin{array}{r}172.57 \\
(697.24) \\
\end{array}$ \\
\hline $\begin{array}{l}\text { Increase in level of GDP per capita (1995 USD) } \\
{[\mathrm{N}=50]}\end{array}$ & $\begin{array}{r}919.10 \\
(1244.75)\end{array}$ & $\begin{array}{r}1004.41 \\
(1491.35)\end{array}$ & $\begin{array}{r}85.30 \\
(341.15) \\
\end{array}$ \\
\hline World Bank Assistance (1990-2000) & Initial & Final & Change \\
\hline $\begin{array}{l}\text { Increase in IBRD and IRD exposure (USD) } \\
{[\mathrm{N}=44]}\end{array}$ & $\begin{array}{r}4.38 \mathrm{e}+08 \\
(4.42 \mathrm{e}+08)\end{array}$ & $\begin{array}{r}6.68 \mathrm{e}+08 \\
(6.07 \mathrm{e}+08)\end{array}$ & $\begin{array}{r}2.31 \mathrm{e}+08 \\
(3.00 \mathrm{e}+08)\end{array}$ \\
\hline
\end{tabular}

Source: Authors' own calculations from data provided by the World Bank.

Notes: 1 . The figures within parentheses are standard deviations.

2. $\mathrm{N}=$ number of observations 
Table 2

Impact of World Bank loans and grants on health in African countries

\begin{tabular}{|c|c|c|}
\hline & Model 1 & Model 2 \\
\hline \multicolumn{3}{|c|}{$\begin{array}{l}\text { Dependent variable: } \\
\text { Change in }(\Delta) \text { mortality rate (per } 1000) \text { prior to } 1^{\text {st }} \text { birthday }(1995-2002)\end{array}$} \\
\hline$\Delta$ IBRD-IDA assistance & $\begin{array}{l}-1.59 \mathrm{e}-08 * * \\
(7.60 \mathrm{e}-09)\end{array}$ & $\begin{array}{r}-1.52 \mathrm{e}-08 * \\
(7.97 \mathrm{e}-09)\end{array}$ \\
\hline$\Delta$ Public health expenditure (\% of GDP) & $\begin{array}{l}0.0016 \\
(0.0024)\end{array}$ & $\begin{array}{l}0.0007 \\
(0.0008)\end{array}$ \\
\hline PPP GDP per capita & $\begin{array}{l}0.4957 \\
(4.1528)\end{array}$ & $\begin{aligned}-2.4247 \\
(3.8287)\end{aligned}$ \\
\hline Constant & $\begin{array}{r}-4.4003 * \\
(2.3127) \\
\end{array}$ & $\begin{array}{r}-4.5619 * \\
(2.6063) \\
\end{array}$ \\
\hline Adjusted R-square & 0.060 & 0.056 \\
\hline $\begin{array}{l}\text { F-statistics } \\
\text { (p-value) }\end{array}$ & $\begin{array}{l}1.93 \\
(0.14)\end{array}$ & $\begin{array}{l}2.93 \\
(0.04)\end{array}$ \\
\hline $\mathrm{N}$ & 36 & 37 \\
\hline \multicolumn{3}{|c|}{$\begin{array}{l}\text { Dependent variable: } \\
\text { Change in }(\Delta) \text { mortality rate }(\text { per } 1000) \text { prior to } 5^{\text {th }} \text { birthday }(1995-2002)\end{array}$} \\
\hline$\Delta$ IBRD-IDA assistance & $\begin{array}{r}-2.00 \mathrm{e}-08^{\otimes} \\
(1.27 \mathrm{e}-08)\end{array}$ & $\begin{array}{r}-2.12 \mathrm{e}-08^{\otimes} \\
(1.42 \mathrm{e}-08)\end{array}$ \\
\hline$\Delta$ Public health expenditure (\% of GDP) & $\begin{array}{l}0.0035 \\
(0.0033)\end{array}$ & $\begin{array}{l}0.0009 \\
(0.0011)\end{array}$ \\
\hline PPP GDP per capita & $\begin{array}{l}3.6124 \\
(5.9875)\end{array}$ & $\begin{aligned}-3.7761 \\
(6.1467)\end{aligned}$ \\
\hline Constant & $\begin{array}{l}-7.7529 * * \\
(3.6108)\end{array}$ & $\begin{array}{r}-6.3493 \\
(4.6216) \\
\end{array}$ \\
\hline Adjusted R-square & 0.051 & 0.07 \\
\hline $\begin{array}{l}\text { F-statistics } \\
\text { (p-value) }\end{array}$ & $\begin{array}{l}1.49 \\
(0.23)\end{array}$ & $\begin{array}{l}2.16 \\
(0.11)\end{array}$ \\
\hline $\mathrm{N}$ & 36 & 37 \\
\hline
\end{tabular}

Notes: 1. In Model 1, PPP GDP per capita is expressed as change during the 19952002 period, while, in Model 2 we use the initial (i.e., 1995) value of the variable.

2. The values within parentheses are standard errors.

3 . $\otimes,{ }^{* * *}, * *$ and $*$ indicate significance at the $15 \%, 10 \%, 5 \%$ and $1 \%$ levels, respectively. 
Table 3

Impact of World Bank loans and grants on education in African countries

\begin{tabular}{|c|c|c|c|c|}
\hline & Model 1 & Model 2 & Model 3 & Model 4 \\
\hline \multicolumn{5}{|l|}{$\begin{array}{l}\text { Dependent variable: } \\
\text { Change in }(\Delta) \text { percen }\end{array}$} \\
\hline$\Delta$ IBRD-IDA assistance & $\begin{array}{c}-1.35 \mathrm{e}-09 \\
(1.02 \mathrm{e}-08)\end{array}$ & $\begin{array}{l}-7.06 \mathrm{e}-10 \\
(9.87 \mathrm{e}-09)\end{array}$ & $\begin{array}{l}-2.23 \mathrm{e}-09 \\
(1.13 \mathrm{e}-08)\end{array}$ & $\begin{array}{c}-1.82 \mathrm{e}-09 \\
(1.11 \mathrm{e}-08)\end{array}$ \\
\hline PPP GDP per capita & $\begin{array}{l}0.0029 \\
(0.0045)\end{array}$ & $\begin{array}{l}0.0025 \\
(0.0044)\end{array}$ & $\begin{array}{l}0.0001 \\
(0.0036)\end{array}$ & $\begin{array}{r}-0.00008 \\
(0.0037)\end{array}$ \\
\hline Adult literacy rate & $\begin{array}{c}-0.2137 \\
(0.1788)\end{array}$ & $\begin{array}{c}-0.1915 \\
(0.1700)\end{array}$ & $\begin{array}{c}-0.1807 \\
(0.3071)\end{array}$ & $\begin{array}{c}-0.1538 \\
(0.3073)\end{array}$ \\
\hline Constant & $\begin{array}{l}11.2028 \\
(10.7089)\end{array}$ & $\begin{array}{l}10.9361 \\
(10.8274)\end{array}$ & $\begin{array}{l}10.5932 \\
(10.4764)\end{array}$ & $\begin{array}{l}10.4142 \\
(10.6427)\end{array}$ \\
\hline Adjusted R-square & -0.160 & -0.171 & -0.180 & -0.186 \\
\hline $\begin{array}{l}\text { F-statistics } \\
\text { (p-value) }\end{array}$ & $\begin{array}{l}0.74 \\
(0.54)\end{array}$ & $\begin{array}{l}0.69 \\
(0.57)\end{array}$ & $\begin{array}{l}0.64 \\
(0.60)\end{array}$ & $\begin{array}{l}0.62 \\
(0.61)\end{array}$ \\
\hline $\mathrm{N}$ & 15 & 15 & 15 & 15 \\
\hline \multicolumn{5}{|l|}{$\begin{array}{l}\text { Dependent variable: } \\
\text { Change in }(\Delta) \text { percen }\end{array}$} \\
\hline$\triangle$ IBRD-IDA assistance & $\begin{array}{l}1.91 \mathrm{e}-08 * * \\
(9.05 \mathrm{e}-09)\end{array}$ & $\begin{array}{l}1.89 \mathrm{e}-08 * * \\
(8.85 \mathrm{e}-09)\end{array}$ & $\begin{array}{l}2.70 \mathrm{e}-08 * * \\
(1.10 \mathrm{e}-08)\end{array}$ & $\begin{array}{l}2.69 \mathrm{e}-08 * * \\
(1.10 \mathrm{e}-08)\end{array}$ \\
\hline PPP GDP per capita & $\begin{array}{c}-0.0059 \\
(0.0048)\end{array}$ & $\begin{array}{c}-0.0057 \\
(0.0048)\end{array}$ & $\begin{array}{l}0.0018 \\
(0.0013)\end{array}$ & $\begin{array}{l}0.0018 \\
(0.0013)\end{array}$ \\
\hline Adult literacy rate & $\begin{array}{l}0.0208 \\
(0.1276)\end{array}$ & $\begin{array}{l}0.0055 \\
(0.1219)\end{array}$ & $\begin{array}{c}-0.1610 \\
(0.1334)\end{array}$ & $\begin{array}{c}-0.1624 \\
(0.1232)\end{array}$ \\
\hline Constant & $\begin{array}{c}-0.8160 \\
(8.7983) \\
\end{array}$ & $\begin{array}{c}-0.0923 \\
(8.9673) \\
\end{array}$ & $\begin{array}{l}0.1784 \\
(8.6579) \\
\end{array}$ & $\begin{array}{l}1.1159 \\
(8.7932) \\
\end{array}$ \\
\hline Adjusted R-square & 0.152 & 0.151 & 0.120 & 0.122 \\
\hline $\begin{array}{l}\text { F-statistics } \\
\text { (p-value) }\end{array}$ & $\begin{array}{l}2.16 \\
(0.12) \\
\end{array}$ & $\begin{array}{l}2.20 \\
(0.12)\end{array}$ & $\begin{array}{l}3.30 \\
(0.04)\end{array}$ & $\begin{array}{l}3.40 \\
(0.03)\end{array}$ \\
\hline $\mathrm{N}$ & 23 & 23 & 23 & 23 \\
\hline \multicolumn{5}{|c|}{$\begin{array}{l}\text { Dependent variable: } \\
\text { Change in }(\Delta) \text { youth literacy rate (1990-2000) }\end{array}$} \\
\hline$\triangle$ IBRD-IDA assistance & $\begin{array}{l}1.74 \mathrm{e}-09^{\otimes} \\
(1.18 \mathrm{e}-09)\end{array}$ & $\begin{array}{l}1.89 \mathrm{e}-09^{\otimes} \\
(1.27 \mathrm{e}-09)\end{array}$ & $\begin{array}{l}1.52 \mathrm{e}-09 \\
(1.51 \mathrm{e}-09)\end{array}$ & $\begin{array}{l}1.43 e-09 \\
(1.60 \mathrm{e}-09)\end{array}$ \\
\hline PPP GDP per capita & $\begin{array}{r}-0.00003 \\
(0.0007)\end{array}$ & $\begin{array}{r}-0.0001 \\
(0.0008)\end{array}$ & $\begin{array}{r}-0.0001 \\
(0.0003)\end{array}$ & $\begin{array}{r}-0.0002 \\
(0.0003)\end{array}$ \\
\hline Adult literacy rate & $\begin{aligned} &- 0.0709 \\
&(0.0561)\end{aligned}$ & $\begin{aligned}-0.0568 \\
(0.0578)\end{aligned}$ & $\begin{array}{r}-0.0659 \\
(0.0619)\end{array}$ & $\begin{array}{r}-0.0468 \\
(0.0629)\end{array}$ \\
\hline Constant & $\begin{array}{l}10.7276^{* * *} \\
(3.4019)\end{array}$ & $\begin{array}{l}10.2904^{* *} \\
(3.7326)\end{array}$ & $\begin{array}{l}10.7440 * * * \\
(3.3550)\end{array}$ & $\begin{array}{l}10.3066 * * \\
(3.6727)\end{array}$ \\
\hline Adjusted R-square & 0.035 & 0.001 & 0.036 & 0.007 \\
\hline $\begin{array}{l}\text { F-statistics } \\
\text { (p-value) }\end{array}$ & $\begin{array}{l}1.87 \\
(0.16)\end{array}$ & $\begin{array}{l}1.72 \\
(0.18)\end{array}$ & $\begin{array}{l}2.13 \\
(0.12)\end{array}$ & $\begin{array}{l}2.21 \\
(0.11)\end{array}$ \\
\hline $\mathrm{N}$ & 29 & 29 & 29 & 29 \\
\hline
\end{tabular}

Note: $\quad$ 1. In Models 1 and 2, PPP GDP per capita is expressed as change during the 1990-2000 period, while, in Models 3 and 4 we use the initial (i.e., 1990) value of the variable. 
2. In Models 1 and 3, we use the initial (i.e., 1990) value of the adult literacy rate, while in Models 2 and 4 we use the mid-period (i.e., 1995) value of the adult literacy rate.

3. The values within parentheses are standard errors.

4. $\otimes, * * *, * *$ and $*$ indicate significance at the $15 \%, 10 \%, 5 \%$ and $1 \%$ levels, respective 


\section{DAVIDSON INSTITUTE WORKING PAPER SERIES - Most Recent Papers}

The entire Working Paper Series may be downloaded free of charge at: www.wdi.bus.umich.edu

CURRENT AS OF 8/8/05

\begin{tabular}{|c|c|c|}
\hline Publication & Authors & Date \\
\hline $\begin{array}{l}\text { No. 784: Does the World Bank have any impact on human development } \\
\text { of the poorest countries? Some preliminary evidence from Africa }\end{array}$ & Sumon Kumar Bhaumik & Aug. 2005 \\
\hline $\begin{array}{l}\text { No. 783: Comparative social capital: Networks of entrepreneurs and } \\
\text { investors in China and Russia }\end{array}$ & Bat Batjargal & July 2005 \\
\hline $\begin{array}{l}\text { No. 782: Exchange Rate Regimes, Foreign Exchange Volatility and } \\
\text { Export Performance in Central and Eastern Europe: Just Another Blur } \\
\text { Project? }\end{array}$ & $\begin{array}{l}\text { Balázs Égert and Amalia } \\
\text { Morales-Zumaquero }\end{array}$ & July 2005 \\
\hline $\begin{array}{l}\text { No. 781: Equilibrium Exchange Rate in the Czech Republic: How Good } \\
\text { is the Czech BEER? }\end{array}$ & Ian Babetskii and Balázs Égert & July 2005 \\
\hline $\begin{array}{l}\text { No. 780: Autonomy and Performance of Foreign Subsidiaries in five } \\
\text { Transition Countries }\end{array}$ & $\begin{array}{l}\text { Urmas Varblane, Katrin Männik, } \\
\text { and Helena Hannula }\end{array}$ & July 2005 \\
\hline $\begin{array}{l}\text { No. 779: The Political Economy of Industrial Policy in China: The Case } \\
\text { of Aircraft Manufacturing }\end{array}$ & Andrea Goldstein & July 2005 \\
\hline $\begin{array}{l}\text { No. 778: Bank Supervision Russian style: Rules versus Enforcement } \\
\text { and Tacit Objectives }\end{array}$ & $\begin{array}{l}\text { Sophie Claeys, Gleb Lanine and } \\
\text { Koen Schoors }\end{array}$ & June 2005 \\
\hline No. 777: Labor Market Trends and Institutions in Belarus & $\begin{array}{l}\text { Zuzana Brixiova and Vera } \\
\text { Volchok }\end{array}$ & June 2005 \\
\hline $\begin{array}{l}\text { No. 776: Can Vietnam Achieve One o } \\
\text { Goals? An analysis of schooling drop }\end{array}$ & $\begin{array}{l}\text { Vo Tri Thanh And Trinh Quang } \\
\text { Long }\end{array}$ & June 2005 \\
\hline $\begin{array}{l}\text { No. 775: Is The Link Between Reforms And Growth Spurious? A } \\
\text { Comment }\end{array}$ & Tomasz Mickiewicz & May 2005 \\
\hline $\begin{array}{l}\text { No. 774: The Risk Aversion of Banks in Emerging Credit markets: } \\
\text { Evidence from India }\end{array}$ & $\begin{array}{l}\text { Sumon Kumar Bhaumik and } \\
\text { Jenifer Piesse }\end{array}$ & May 2005 \\
\hline $\begin{array}{l}\text { No. 773: Organized Labor and Restructuring: Coal Mines in the Czech } \\
\text { Republic and Romania }\end{array}$ & $\begin{array}{l}\text { Jan Bruha, Delia Ionascu, and } \\
\text { Byeongju Jeong }\end{array}$ & May 2005 \\
\hline $\begin{array}{l}\text { No. 772: Is Political Risk Company-Specific? The Market Side of the } \\
\text { Yukos Affair }\end{array}$ & $\begin{array}{l}\text { Alexei Goriaev and Konstantin } \\
\text { Sonin }\end{array}$ & May 2005 \\
\hline $\begin{array}{l}\text { No. 771: Non-Linear Exchange Rate Dynamics in Target Zones: A } \\
\text { Bumpy Road Towards A Honeymoon }\end{array}$ & $\begin{array}{l}\text { Jesús Crespo-Cuaresma, Balázs } \\
\text { Égert, and Ronald MacDonald }\end{array}$ & May 2005 \\
\hline $\begin{array}{l}\text { No. 770: Equilibrium Exchange Rates in Southeastern Europe, Russia, } \\
\text { Ukraine and Turkey: Healthy or (Dutch) Diseased? }\end{array}$ & Balázs Égert & May 2005 \\
\hline $\begin{array}{l}\text { No. 769: Equilibrium Exchange Rates in Central and Eastern Europe: A } \\
\text { Meta-Regression Analysis }\end{array}$ & Balázs Égert and László Halpern & May 2005 \\
\hline $\begin{array}{l}\text { No. 768: Testing for inflation convergence between the Euro Zone } \\
\text { and its CEE partners }\end{array}$ & Imed Drine and Christophe Rault & Apr. 2005 \\
\hline $\begin{array}{l}\text { No. 767: Labor Mobility during Transition: Evidence from the Czech } \\
\text { Republic }\end{array}$ & Jan Fidrmuc & Apr. 2005 \\
\hline $\begin{array}{l}\text { No. 766: Formation of social capital in Central and Eastern Europe: } \\
\text { Understanding the gap vis-à-vis developed countries }\end{array}$ & Jan Fidrmuc and Klarita Gërxhani & Apr. 2005 \\
\hline $\begin{array}{l}\text { No. 765: Do Regional Integration Agreements Increase Business-Cycle } \\
\text { Convergence? Evidence From APEC and NAFTA }\end{array}$ & $\begin{array}{l}\text { Viviana Fernandez and Ali M. } \\
\text { Kutan }\end{array}$ & Apr. 2005 \\
\hline $\begin{array}{l}\text { No. 764: State Regulations, Job Search and Wage Bargaining: A Study } \\
\text { in the Economics of the Informal Sector }\end{array}$ & Maxim Bouev & Apr. 2005 \\
\hline $\begin{array}{l}\text { No. 763: The Feldstein-Horioka Puzzle Revisited: An “European- } \\
\text { Regional” Perspective }\end{array}$ & $\begin{array}{l}\text { Jérôme Hericourt and Mathilde } \\
\text { Maurel }\end{array}$ & Apr. 2005 \\
\hline $\begin{array}{l}\text { No. 762: Transatlantic Differences in Labour Markets Changes in Wage } \\
\text { and Non-Employment Structures in the 1980s and the 1990s }\end{array}$ & Patrick A. Puhani & Mar. 2005 \\
\hline $\begin{array}{l}\text { No. 761: Resolution, Recovery and Survival: The Evolution of Payment } \\
\text { Disputes in Post-Socialist Europe }\end{array}$ & William Pyle & Mar. 2005 \\
\hline $\begin{array}{l}\text { No. 760: Official Foreign Exchange Interventions in the Czech } \\
\text { Republic: Did They Matter? }\end{array}$ & Balázs Égert and Luboš Komárek & Mar. 2005 \\
\hline $\begin{array}{l}\text { No. 759: Assessing Market Expectations on Exchange Rates and } \\
\text { Inflation: A Pilot Forecasting System for Bulgaria }\end{array}$ & $\begin{array}{l}\text { Michael Berlemann, Kalina } \\
\text { Dimitrova, \& Nikolay Nenovsky }\end{array}$ & Mar. 2005 \\
\hline
\end{tabular}

